\title{
The management level of logistics customer service industrial enterprise
}

\author{
Y.V. Butrina ${ }^{1, *}, V . N$. Tishina ${ }^{1}$, and P.Y. Tishin ${ }^{1}$ \\ ${ }^{1}$ South Ural State University, Chelyabinsk, Russia
}

\begin{abstract}
This article deals with some aspects of the logistics service of industrial enterprise customers, current approaches to its management, namely, measurement, evaluation and optimization. It describes the effect of the level of customer service in the business results. How the concept of "logistics service users" is formulated. The author's index of evaluating the effectiveness of the logistics customer service - "logistics leverage". Author's universal measurement system of the logistics maintenance level, serving industrial enterprise customers is presented, including 11 indicators criteria values and integral indicator. The optimal values of parameters can be different for different categories of customers who prefer low, medium and high level of logistics services. It substantiates the practical significance of the study through tested at Chelyabinsk Electrode Plant.
\end{abstract}

\section{Introduction}

Modern business conditions are characterized by a fairly high level of competition. In this situation, low price (or slightly different from the prices of competing companies), high-quality products and services, a wide range of products, the continuous improvement of products (works, services) are not always the main factors of success in the market. Many consumers must be listed along with quality service.

Companies are turning to the level of customer service as a mean to improve competitiveness. Currently, customers prefer enterprises that can deliver the goods by a certain date, in the required amount, convenient packaging, reasonable lot size, in accordance with the ordered assortment, etc. [1]. In some cases, the level of service is given more importance than the cost of the provision of services [2]. In Russian companies there are problems in the service, namely the "poor quality of service, lack of reliability, ..., lack of proper openness and "transparency"... [3].

Currently, experts point out that the competition between enterprises is enhanced by the level of customer service. Customers are becoming more demanding, expecting more personal service.

\section{Relevance: scientific significance of the issue with a brief review of the literature}

Logistic management of industrial enterprises in the US and Western Europe have been paying considerable attention to the 70 -ies of the last century. One of the first industries to apply the concept of logistics, the automotive industry has become. The importance of logistics customer service and the basic approaches to its management were first reflected in the works of world-renowned scholars and practitioners as R.H. Ballou [4], D.J. Bowersox, D.J. Closs [5], D. Waters [2], M. Christopher [6], J. Gattorna [7, 8], J.S. Johnson, D.F. Wood, D.L. Vordlou, P. Murphy-jr. [9], M.R. Linders, H.E. Fearon [10] and others.

M. McGinnis after order fulfillment analysis revealed that currently the level of service is given more importance than the cost of the provision of services [11].

Since 2000 , the number of scientific and practical research in this area has increased significantly. Firstclass service as the basis of competitive advantage considered J. Tschohl [12]. Some researchers, such as D. Mourtzis, considering the current trend of individualization of logistics services in the production [13]. There was a separate area - "clientoriented service" [14]. Some authors pay attention to the performance of logistic service [15].

Among the Russian scientists, including those who engaged in management consulting business leaders, their work should be noticed, namely V.I. Sergeyev [16], L.B. Mirotin [17], B.A. Anikin [18], Y. Tashbayev [19], A.A. Chebotaev, D.A. Chebotaev [20] and other

In studying the works of the above we had identified about 90 different indicators, in varying degrees, allowing to measure the level of logistics services [21]. The analysis of these parameters allowed to express the following conclusions.

1. Authors are limited only by the concepts of performance without giving definitions. 
2. There is a weak formalization of logistical service level parameters and their definitions.

3. No classification performance.

4. Some indicators do not directly relate to the logistics activity, for example, partners honesty.

5. Do not set the criteria for measuring the limit performance, service standards.

6. No integral indicator of the level of service.

7. The indicators do not form a system, some indicators contradict each other.

8. There is no indication on the priority of one over the other indices.

9. Not considered data collection mechanism and evaluation of the service level indicators.

In the literature, there are various methods of evaluating the performance of suppliers, developed assessment scale [22], which can be conventionally used to measure the level of customer service of any company. To select the parameters you can use surveys of consumers. After that service standards need to bring to the customer, it is an important tool of competition. Possible market segmentation and providing different levels of service for different market segments.

To manage the logistics activities of industrial enterprises needed to measure the quality of logistics services. For this purpose, defined (criteria) parameters of quality of service and management of these parameters is performed so that the discrepancy between the expected and actual levels of selected criteria (parameters) were minimal. For this there are different methods of assessment: questionnaires to customers and potential customers, expert opinions, statistical methods, etc.

The difficulty lies in the fact that most of the parameters of quality of service can not be measured quantitatively, i.e. receive a formal evaluation. In most cases we have to use qualitative descriptions like: above, below better - worse reliably - is not reliable, less likely - more likely, more affordable less available, etc.

The following analysis of the literature showed that there are currently no methods of evaluating the level of customer service that fully meet the following requirements: consistency, completeness of information, the use of measurable indicators, a comprehensive system of indicators and criteria, reliability of results, ease of collecting baseline data, use of results, etc.

Therefore, author's method of estimating the level of service is shown in order to improve the level of customer service evaluation developed.

\section{Level of logistics customer service}

The main element of the service level is the speed (time) services, it is important for the majority of consumers. Customer service is the responsibility of marketing and logistics. Marketing identifies and often creates the need for a particular product (works, services) through advertising. A quality logistics helps to meet this need. Serving users is "Product" of logistics [19]. But marketing and logistics services interpreted in different ways.

Let's introduce the concept of "logistics service users". It is necessary to distinguish the level of service on the level of logistics services, which is its integral part. That is, to the level of performance of logistics services will refer only to those which depend on the level of enterprise logistics. For example, indicators such as honesty, friendliness of staff, etc., in our opinion, does not reflect the efficiency of enterprise logistics for the consumer, but in general are associated with the service and are marketing competence.

One of the known definitions of logistics means the ability to ensure the availability of the right product in the desired quantity and quality specified in the right place at the scheduled time for a particular customer with the best cost. This definition emphasizes the importance of service. Customer service - a set of activities carried out during the execution of orders, to meet their needs and aimed at the creation of the clients idea of the reliability of the relationship with this company [9]. Customer service - the process of creating substantial benefits, containing added tax, subject to maintaining an effective level of costs in the supply chain. This way, the customer service is considered as a process aimed at supply chain management [19]. Logistics service performs an integrating function. Such a function is shown in the interaction of the functional areas of logistics in order to meet consumers. Order fulfillment is at the center of attention service system. Warehousing, inventory management, transportation, order management, etc. - is part of the implementation of the order and customer service.

If we consider the logistics services from the point of view of the industrial enterprise, it is a set of technologies, techniques, methods of enterprise interactions with customers to ensure continuous communication between the time of ordering and completion of its implementation with a view to longterm customer satisfaction.

The level of logistics services - is the degree of customer satisfaction expressed in the proper execution of orders, there is no error, the effective provision of services and constant striving to improve the level of service, as well as under the level of customer service standards, terms of the contract or the usual requirements for quality of service [19].

Assess the level of customer service is only possible when it is measured, ie obtaining quantitative assessment of the degree of customer satisfaction. Measuring the level of customer service in logistics is not possible without the use of specialized tools in the form of a system of performance indicators. It allows you not only to measure the level of achievement of planned results (such as reliability, accuracy of orders, etc.), But also to monitor the dynamics on the integral and particular indicators.

Service level indicators of each company can sufficiently differ from each other due to their sphere 
of activity, types of products or services, consumer demand, etc., and therefore. Nevertheless, the key factor here is the turnaround time as the period between placing and order fulfillment.

In the literature, there are various methods of evaluating the performance of suppliers, developed assessment scale [21], which can be conventionally used to measure the level of customer service of any company. To select the parameters you can use surveys of consumers. After that service standards need to bring to the customer, it is an important tool of competition. Possible market segmentation and providing different levels of service for different market segments.

According Rodnikov A.N., the level of service is a comprehensive index, calculated on set criteria, the composition of which may vary in different systems. The most important - is the ability of the logistics system to ensure delivery of the right product to the consumer due to the time and space required. Calculated as the probability of the delivery of the ordered goods in the required time in the right place and is not less than 0.95 in real logistic systems [23].

Customer service level should be viewed as an integral component, which includes many options logistics services, such as lead time, a willingness to supply, range, fidelity deliveries, accuracy of the order, the availability (probability of occurrence of a shortage of goods, the saturation rate of demand; the frequency of the completeness of inventories coverage orders for delivery); features (speed of order execution, supply continuity, flexibility, ie nonstandard orders execution); reliability (compliance regulations demand stocks); Territorial convenience and others. In the study of a large number of different works on logistics and supply chain management, as well as the results of economic activity of the enterprises we have identified and analyzed about 90 of such indicators.

The company, created its own system of service level indicators, can measure the effectiveness of the level of service, and also to compare the results with those of other enterprises. This allows you to define new targets to improve the effectiveness of its activities. Focused logistics service strategy is a means to improve market efficiency and competitive differentiation for firms employing logistics [24]. "The level of logistics customer service directly affect the market share of the company, its overall logistics costs and, ultimately, profitability, determining not only the loyalty of existing customers, but also the number of its potential customers, which will be the actual" [16].

In many areas the result of quality service are repeat orders from customers. Proven methods of high-quality customer service can be applied to the whole logistics channel [9]. Currently, consumer demand is largely determined by the level of service. Studies in European enterprises show that the reputation of the company has a greater influence on customer orientation. This factor is most important for more than $90 \%$ of enterprises [26].
It is necessary to monitor the rate of logistics services in the dynamics. In the process of monitoring identified gaps, and where the company lags behind the demands of consumers, corrective actions can be carried out. It is advisable to analyze the level of service direct competitors for benchmarking procedure. When performance indicators exceed market requirements, there are two possible ways of development. You can either cut the process to a suitable level in order to reduce costs at the same time, or continue to develop them as a criterion for receiving the order.

Tasks of improving logistics services have to be extremely specific. For example, "97\% of all orders must be carried out completely and accurately, and the goods shipped within 24 hours after receipt of order" [9].

It is important that in this case used clear and measurable indicators, eg [5]:

1) availability of stocks according to the classification for the $\mathrm{ABC}$ analysis: $99 \%$ of the goods of group $\mathrm{A}$, $95 \%$ for products of Group B, $90 \%$ for the products of the group;

2) delivery of $98 \%$ of orders within 48 hours after receipt of the order;

3) additional delivery on the understaffed orders must be made within 5 days, and others.

Large network of mass US retailers such as WalMart, Kmart and Target show to suppliers following requirements: at least $98 \%$ compliance with an order, lack of orders return, shipping within the prescribed period, marking the universal codes of goods, equipment for specific customers, advance notification of shipment [9].

Currently, buyers dictate their demands. The level of customer tolerance for errors of suppliers is gradually reduced. In the United States ten years ago, the buyer was in a $1 \%$ error in carrying out the order, five years ago $-0.5 \%$, and today - only $0.1 \%$ error [9]. As for Russian companies, the distribution centers network "Pyaterochka" supermarket, the number of errors in order picking in recent years has decreased from $5 \%$ to $0.5 \%$ [26].

To improve the level of logistics services customers need to develop measures to improve logistics customer service.

We offer measuring logistics performance index of "logistics leverage" the essence of which lies in the comparison of service levels and costs required to achieve it:

$$
L L=\text { level of service / logistics costs }
$$

LL indicates what level of service (percentage) achieved an attachment 1 ruble ( 1 ths. Rubles to 1 million rubles, etc.).

On the one hand, this index contains two basic criteria logistics.

On the other hand, they are mutually opposite, since a high level of maintenance typically requires significant largest costs. However, they are interdependent. The indicator is a system, because It 
evaluates the efficiency of the entire logistics of the company.

Unit $L L-\% /$ ruble ( $\% /$ thousand rubles, $\% / \mathrm{mln}$, etc.). As the need to reduce logistics costs, while seeking to improve customer service levels, the value of the index should strive to the maximum or target value.

Let's proceed to the measurement and evaluation of the level of logistical service of industrial enterprise customers.

Level of performance of logistic service systems can be quite different in different circumstances. However, the key factor here is the lead time as the period between the placement and execution of the order. Indicators of logistics services can be categorized as followed:

1) the measurability: quantitative, qualitative;

2) integrated assessment: complex, simple;

3) with respect to time during the period (floating), at time (static);

4) comparing the degree: absolute; relative;

5) the frequency of observations: the permanent, periodic;

6) by priority (importance) for consumers: significant, less significant, insignificant;

7) on the application: universal, special;

8) scale: general, single;

9) the nature of the evaluation: positive, negative;

10) on units of measurement: cost, in terms of time, in physical units (units of measurement of mass, volume, etc.).

11) by the number of influencing factors: singlefactor, multi-factor.
From the set of indicators discussed in the literature and used in practice management companies (90), detected and analyzed by us, as the level of logistics service system of indicators will take the ones that are most objective and complete, in our opinion, reflect the efficiency of logistics for customers, provide measurability and clarity, and which can be adjusted depending on the specific conditions if necessary (see table 1).

Since the term of the order is the main parameter of the level of service, it uses 3 different parameters (serial numbers 1, 2, 3) to measure it in the system.

Further indicators are determined by weight. Determining the weights should be done by skilled team of experts from the number of customers of this company. The group should be a representative sample of the total number of consumers. Matrix allows to set priorities among the indicators. Matrix that is ready to calculate each indicator rating has the form shown in the table II.

Comparison of produced is done in pairs.. For example, with the first is compared with the second, then the third, with fourth, etc.; then the second is compared with the third, fourth, fifth, etc. Most important from the point of view of experts criterion is attributable to a INDICATE-value "1" less important - "0". After this result for each indicator is added, and all amounts are reduced to a common denominator, that is the total number of indicators. That is how we obtain the weight of each indicator.

Table 1. The level of logistic service indicator.

\begin{tabular}{|c|c|c|}
\hline Indicator of level measurement & The meaning of the formula & $\begin{array}{l}\text { The criterion of the } \\
\text { effective } \\
\text { ness of the logistics } \\
\text { service level }\end{array}$ \\
\hline 1. Term of order fulfillment & $\begin{array}{l}\text { The period of time between the moment of registration of the } \\
\text { application and implementation of supply (provision of services, } \\
\text { execution of works) }\end{array}$ & $\rightarrow \min$ \\
\hline $\begin{array}{l}\text { 2. Compliance with the expectations of } \\
\text { the consumers to the actual time of the } \\
\text { order }\end{array}$ & $\begin{array}{l}\text { The number of applications, timing of which correspond exactly to } \\
\text { the expectations of customers * } 100 \% \text { / total number of client } \\
\text { requests. }\end{array}$ & $\rightarrow 100 \%$ \\
\hline $\begin{array}{l}\text { 3. Precise execution of orders on terms } \\
\text { (continuity) }\end{array}$ & $\begin{array}{l}\text { Number of orders, timing of which in fact correspond exactly to the } \\
\text { terms of contracts } * 100 \% / \text { total number of customer orders. }\end{array}$ & $\rightarrow 100 \%$ \\
\hline $\begin{array}{l}\text { 4. Lack of product scarcity (the ability to } \\
\text { perform work, services) }\end{array}$ & The probability of the absence of production deficit. & $\rightarrow 100 \%$ \\
\hline 5. The completeness of the range & Number of SKUs into the * $100 \%$ / number of required SKUs. & $\rightarrow 100 \%$ \\
\hline 6. Accuracy of order fulfillment & $\begin{array}{c}\text { The number of applications, the run options that in fact correspond } \\
\text { exactly to the terms of contracts * } 100 \% \text { / Total orders. }\end{array}$ & $\rightarrow 100 \%$ \\
\hline 7. Willingness to orders & $\begin{array}{l}\text { The number of orders that have the same customer requests * } 100 \% \\
\text { / number of client requests. }\end{array}$ & $\rightarrow 100 \%$ \\
\hline 8. Flexibility of order fulfillment & $\begin{array}{l}\text { The number of changes made to orders being implemented * } 100 \% \\
\text { / number of customer requests for change orders. }\end{array}$ & $\rightarrow 100 \%$ \\
\hline 9. Information support & $\begin{array}{l}\text { Number of fast and accurate responses to customer requests / total } \\
\text { number of client requests. }\end{array}$ & $\rightarrow 100 \%$ \\
\hline $\begin{array}{l}\text { 10. Correspondens to the level of service } \\
\text { costs }\end{array}$ & $\begin{array}{l}\text { Striking a balance on two criteria: the level of logistics services and } \\
\text { the costs it. }\end{array}$ & $\rightarrow 100 \%$ \\
\hline
\end{tabular}


Table 2. Determination of the scale service level indicators.

\begin{tabular}{|c|c|c|c|c|c|c|c|c|c|c|}
\hline Indicator & 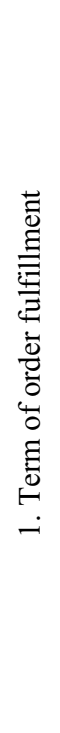 & 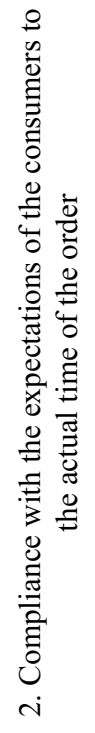 & 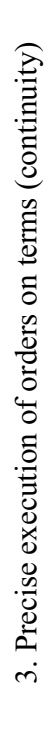 & 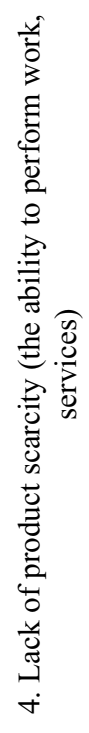 & 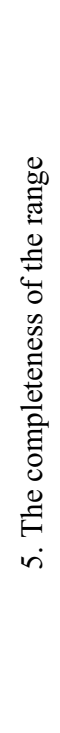 & 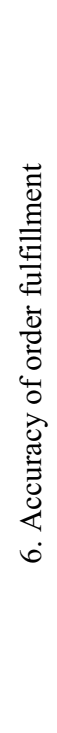 & 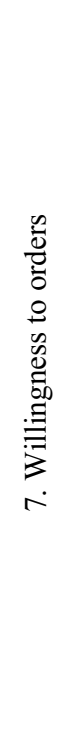 & 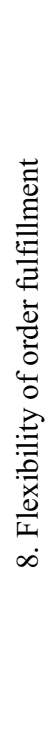 & 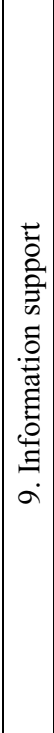 & 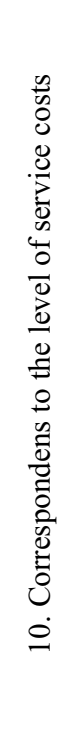 \\
\hline \multicolumn{11}{|l|}{ 1. Term of order fulfillment } \\
\hline \multicolumn{11}{|c|}{$\begin{array}{l}\text { 2. Compliance with the expectations of the } \\
\text { consumers to the actual time of the order }\end{array}$} \\
\hline \multicolumn{11}{|c|}{$\begin{array}{l}\text { 3. Precise execution of orders on terms } \\
\text { (continuity) }\end{array}$} \\
\hline \multicolumn{11}{|c|}{$\begin{array}{l}\text { 4. Lack of product scarcity (the ability to } \\
\text { perform work, services) }\end{array}$} \\
\hline \multicolumn{11}{|c|}{ 5. The completeness of the range } \\
\hline \multicolumn{11}{|c|}{ 6. Accuracy of order fulfillment } \\
\hline \multicolumn{11}{|l|}{ 7. Willingness to orders } \\
\hline \multicolumn{11}{|c|}{ 8. Flexibility of order fulfillment } \\
\hline \multicolumn{11}{|l|}{ 9. Information support } \\
\hline \multicolumn{11}{|c|}{$\begin{array}{l}\text { 10. Correspondens to the level of service } \\
\text { costs }\end{array}$} \\
\hline Points & & & & & & & & & & \\
\hline Weight of the indicator & & & & & & & & & & \\
\hline
\end{tabular}

Then the integral indicator of the level of logistics customer service is calculated. It is a weighted average value, ie, the sum of products of values of service parameters and their weights divided by the sum of the weights.

\section{Practical implementation of the method of logistics level of customer service at the industrial enterprise}

Certain provisions of the presentation-service logistics management system are repeatedly reported and approved at the scientific-practical conferences of different levels, as well as various business forums held in Chelyabinsk.
The results of the consulting activities of authors of this article allow us to judge the effectiveness of the proposed method.

Here are details of the results of measuring the level of logistics services to the industrial plant of "Energoprom - Chelyabinsk Electrode Plant" in March 2016 (see table 3).

Table 3. The level of logistic service indicator "energoprom chelyabinsk electrode plant".

\begin{tabular}{|c|c|c|}
\hline Name of the indicator & $\begin{array}{c}\text { Index of the } \\
\text { indicator, \% }\end{array}$ & $\begin{array}{c}\text { Weight } \\
\text { of the } \\
\text { indicator }\end{array}$ \\
\hline $\begin{array}{c}\text { Term of order } \\
\text { fulfillment }\end{array}$ & 75 & 0.15 \\
\hline 2. Compliance with the \\
expectations of the
\end{tabular}




\begin{tabular}{|c|c|c|}
\hline $\begin{array}{l}\text { consumers to the actual time } \\
\text { of the order }\end{array}$ & & \\
\hline $\begin{array}{l}\text { 3. Precise execution of } \\
\text { orders on terms (continuity) }\end{array}$ & 87 & 0.14 \\
\hline $\begin{array}{l}\text { 4. Lack of product scarcity } \\
\text { (the ability to perform work. } \\
\text { services) }\end{array}$ & 84 & 0.09 \\
\hline $\begin{array}{l}\text { 5. The completeness of the } \\
\text { range }\end{array}$ & 74 & 0.11 \\
\hline $\begin{array}{l}\text { 6. Accuracy of order } \\
\text { fulfillment }\end{array}$ & 82 & 0.09 \\
\hline 7. Willingness to orders & 78 & 0.09 \\
\hline $\begin{array}{l}\text { 8. Flexibility of order } \\
\text { fulfillment }\end{array}$ & 72 & 0.07 \\
\hline 9. Information support & 90 & 0.06 \\
\hline $\begin{array}{l}\text { 10. Correspondens to the } \\
\text { level of service costs }\end{array}$ & 71 & 0.09 \\
\hline
\end{tabular}

So, the integral service level logistics enterprises in March was $73.68 \%$, which corresponds to the average level. The results do not meet the company's management as well as the planned increase in the number of clients. In the future, Chelyabinsk Electrode Plant will regularly measure and evaluate the level of logistics customer service, and also implement measures to improve service levels.

\section{Conclusion}

So, guiding logistics strategy for customer service, organizations industrial enterprises can achieve sustainable and long-term competitive advantage Despite the importance of the level of service currently in the theory and practice are not fully worked out the question of organizing a system of indicators, criterion scale evaluation and an integral indicator to measure the level of service.. For reliable response level logistics service system of indicators should be realistically measured, objective, related to the current and past results, comparable with other companies and other time periods, understandable to all interested parties, allow to identify problem areas.In this regard, the authors proposed an approach of measuring and assessing the level of logistics customer service, which should allow industrial companies to become more efficient.

The developed method allows to estimate the level of logistics customer service for individual indicators, as well as get an overall assessment of the level of service by means of an integral indicator of the level of service to individual orders section, categories of consumers and for the whole company, to conduct benchmarking procedure. This technique can also be used to assess suppliers and business partners (eg, contractors).

The work was supported by Act 211 Government of the Russian Federation, contract № 02.A03.21.0011

\section{References}

1. A.M. Gadghinski, Logistics (Marketing, Moscow, 2013)
2. D. Waters, Logistics: An Introduction to Supply Chain Management: Palgrave Macmillan (Palgrave, 2002)

3. Logistics, 2, 20-22 (2003)

4. R.H. Ballou, Business Logistics Management (Prentice-Hall International, Inc., 1993)

5. D.J. Bowersox, D.J. Closs, Logistical Management (New York, 1996)

6. M. Christopher, Logistics and Supply Chain Management: Strategies for reducing cost and improving service (Prentice-Hall, NJ, 1998)

7. J. Gattorna, Gower Handbook of Supply Chain Management (Taylor \& Francis Ltd Gower, 2003)

8. R.P. Kampstra, J. Ashayeri, J.L. Gattorna, The International Journal Of Logistics Management, 17, 3, 312-330 (2006)

9. J.S. Johnson, D.F. Wood, D.L. Vordlou, P. Murphy, Modern logistics (Williams, Moscow, 2002)

10. M.R. Linders, H.E. Fearon, Manage supply and inventory. Logistics (LLC Victoria plus, St. Petersburg, 2002)

11. D. Waters, Logistics. The supply chain management (Uniti-DANA, Moscow, 2003)

12. J. Tschohl, Achieving Excellence Through Customer Service 7th edition best sellers publishing minneapolis (2013)

13. D. Mourtzis, Challenges and future perspectives for the life cycle of manufacturing networks in the mass customisation era, 1-20

14. Y. Lin, S. Pekkarinen, S. Ma, International Journal Of Logistics Management, 26, 1, 195-214 (2015)

15. O. Bouzaabia, van Riel, A.C.R., J. Semeijn, Journal of Service Management, 24, 2, 112-129 (2013)

16. V.I. Sergeev, Corporate logistics. 300 answers to questions of professionals (INFRA-M, Moscow, 2005)

17. L.B. Mirotin, Y. Tashbaev, O.G. Poroshina, Efficient logistics (Publishing House Examination, Moscow, 2003)

18. B.A. Anikin, Logistics (INFRA-M, Moscow, 2003)

19. L.B. Mirotin, Y. Tashbaev, A.G. Kasenov, Logistics: customer Service (INFRA-M, Moscow, 2002)

20. A.A. Chebotaev, D.A. Chebotaev, Logistics and distribution management (Economics, Moscow, 2012)

21. Y.V. Butrina, The methodology of optimization of the level of customer service and costs in the logistics system business (monograph) (SUSU, Chelyabinsk, 2012)

22. V.E. Nikolaichuk, Procurement and production logistics (St. Petersburg, 2001)

23. A.N. Rodnikov, Logistics: terminologists. Dictionary (INFRA-M, Moscow, 2000)

24. E.A. Golikov, Marketing and logistics (Pashkov, Moscow, 2001)

25. A. Kranke, Loss image loss of customers, 1, 10-14 (2004)

26. SCM day - talk about important, 9, 52-53 (2004) 